\title{
Proceedings
}

\section{Analysis of the Changes in the Valuable Wood Market in RDSF Krosno ${ }^{+}$}

\author{
Dariusz Zastocki ${ }^{1}$, Jarosław Oktaba ${ }^{{ }^{*}}$ and Hubert Lachowicz ${ }^{1}$, \\ 1 Warsaw University of Life Sciences, Institute of Forests Sciences, Department of Forest Utilization; \\ dariusz_zastocki@sggw.edu.pl \\ * Correspondence: jaroslaw_oktaba@sggw.edu.pl; Tel.: +48-22 5938135 \\ + Presented at the 1st International Electronic Conference on Forests, 15-30 November 2020; \\ Available online: https://sciforum.net/conference/IECF2020 \\ Published: 25 October 2020
}

\begin{abstract}
Timber market is very unusual: despite the fact that it affects the economic behavior of consumers and suppliers, the exchange of goods such as wood is conditioned by the needs and ecological principles of silviculture. Sale of wood in Poland, due to the dominant position of the State Forests, is supervised by the Office of Competition and Consumer Protection. One of the acceptable forms of wood sale are submissions. Usually, small amounts of wood with unusual features are offered here for a specific group of customers.Regional Directorate of State Forest (RDSF) Krosno is located in the south-eastern part of Poland and manages a forest area of approximately 400,000 hectares. Annual timber harvesting amounts to approx. 2 million m3, of which less than 2,000 $\mathrm{m} 3$ annually is allocated to the submissions. The paper presents the sale results and prices of veneer wood obtained in submissions and in other forms of timber sale in the territory of the Krosno RDSF in the years 2000-2019.The presented data, due to their 20-year continuity, make it possible to trace changes in the quantity of wood offered, the species structure, and price trends for individual species against the background of the economic situation in relation to the average prices obtained from other methods of sale.
\end{abstract}

Keywords: Valuable wood; Wood submission; Wood price

\section{Introduction}

The State Forests implement the tasks provided for in the Act on Forests of 1991 on the basis of a self-financing system [1]. This means that the State Forests, while implementing their goals, operate on a commercial basis (public sector company) and most of the expenses must cover from own income, i.e. from the sale of wood.

The State Forests, supplying wood directly to the wood industry, had to develop new rules for selling wood based on modern marketing but due to the fact that it holds a dominant position on the market, it is supervised by the Office of Competition and Consumer Protection.

Several methods of selling wood raw material have been developed, among which submissions, tenders and auctions for wood have been in force since 1998. For many years, it has been an effective and proven way of selling valuable wood, which occurs sporadically in the specific stand conditions of the Krosno RDSF.

The precious wood submissions organized in this area bring material benefits as well as prestige for the region and the economy of the State Forests $[2,4,5,6,7]$. The organization of the submissions requires a lot of work due to the complicated and laborious procedure of its preparation and the specificity of the product.

Every year, the Regional Director issues guidelines for the organization of the precious wood submissions, which include, inter alia, information about the technical requirements that must be met by wood prepared for the submissions. "Precious" or "valuable" wood should be understood as 
wood not always compliant with general standards, but endowed with specific features that make it unique. Usually it is wood that meets the standard for veneer wood, but often also wood that does not meet this standard, which can potentially interest buyers with its properties such as large-size wood with features similar to veneer wood or sycamore wood for veneers and musical instruments.

Technical requirements for wood raw material and species offered to potential buyers result mainly from trends in the wood industry [3]. The highest quality wood has always found its buyers quickly and its additional advantage was collecting it in one place. Due to the prestige and obtained prices, more and more Regional Directorates of the State Forests organize submissions of valuable wood, and one of the first was RDSF in Krosno.

The aim of the study was a detailed analysis of the quantity and obtained prices of individual types of wood offered on precious wood submissions taking place in the Krosno RDSF in 2000-2019. The paper presents the income obtained from the sale of wood organized by the RDSF in Krosno and conclusions were drawn about the accuracy of the decisions made on the basis of financial benefits obtained from this form of sale of wood.

\section{Material and Methods}

Information on the quantity of wood sold and the prices obtained on the precious wood submission were taken from the annual reports of the RDSF in Krosno on the acquisition and sale of raw wood and from the annual reports on the sales prices of individual assortments depending on the form of sale in the years 2000-2019.

In the field, however, after selecting wood made according to the adopted assumptions, the sorter makes a decision to qualify it for sale during the submissions. The wood is sent to submissive yards, where the individual pieces of wood are given the so-called commercial appearance.

The wood is arranged according to species and measured, and then, after assigning a submissive number (the so-called lot), a catalog of valuable wood intended for sale is prepared. The wood prepared in this way can be viewed by potential buyers for about two weeks before the start of the submissions. After all offers collected from potential buyers are entered into the computer database, the one that offered the highest price wins. In the case of several equal price offers, the buyer is randomly selected by a computer system. After the settlement of the submissions, the Director of the Regional Directorate of State Forests, on behalf of forest districts, signs contracts with contractors within seven days, who collect the wood material after paying.

\section{Results and Discussion}

For 20 years of the history of the Krosno's submissions has offered a total of over 30,000 m3 of wood raw material. About $95 \%$ of the offered raw material was sold on average.

The data presented in Fig. 1 clearly indicate the collapse of the offer in 2008-2009, which was related to the economic crisis. From year 2012, a slow increase in the offer can be noticed until 2019. The analysis of wood sales on the valuable wood submission in the years 2000-2019 showed that the sales of such types as beech and oak dominate, which results mainly from the species structure of Carpathian stands. The species most often sold in the analyzed period is beech in the amount of $11,783.86 \mathrm{~m}^{3}$, which accounted for $38.02 \%$ of the total amount of wood sold (Fig. 2). beech is primarily used by the veneer industry. In the years 2000-2008, beech dominated the total amount of wood sold at the submission, while its share was lower since 2009.

Since the beginning of the precious wood submission, oak wood has been exhibited, $8485.77 \mathrm{~m}^{3}$ of which was sold, and its share in the total sale was $27.38 \%$. Since 2007 , there has been a clear increase in the amount of oak wood sold, while in 2010-2019 wood of this species dominated the submissions, which was caused by an increase in interest in it and greater use in the wood industry.

The demand for sycamore wood results from the presence of resonance wood features in this species, mainly used for the production of musical instruments. The demand for sycamore wood grew steadily in 2000-2004, and in the following years there was a decline in interest. In the entire analyzed period, sycamore wood accounted for $16.19 \%$ of the total amount of wood sold in the submissions. Black alder and ash wood are also purchased on the precious wood submission, and 
their share in total sales was 6.02 and $5.47 \%$, respectively. Due to the small quantities and the sporadic nature of the offer, the "others" category includes birch, walnut, cherry, maple, linden, larch, pine, poplar and elm wood.

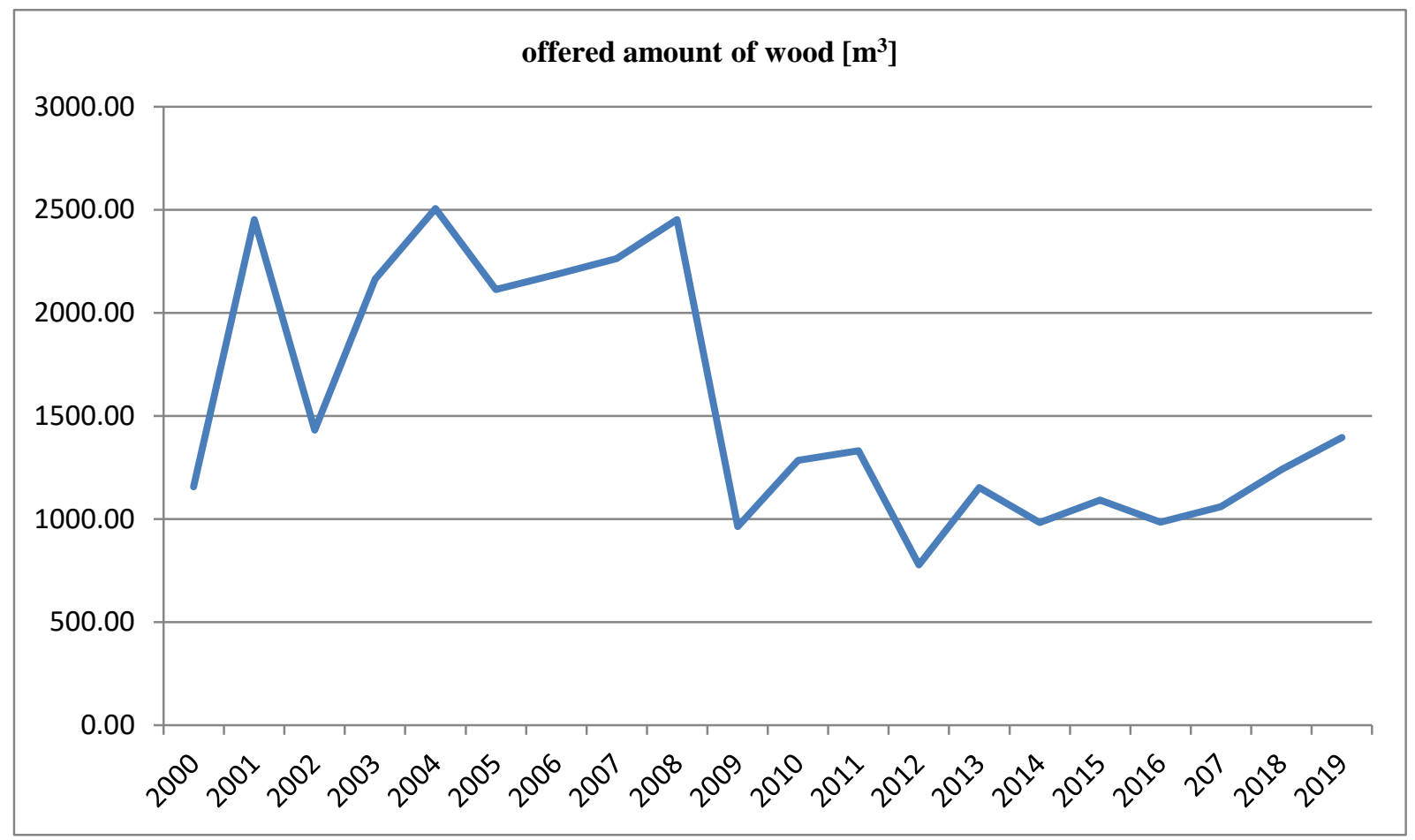

Fig. 1 Offered amount of wood on RDSF Krosno submissions (in $\mathrm{m}^{3}$ ).

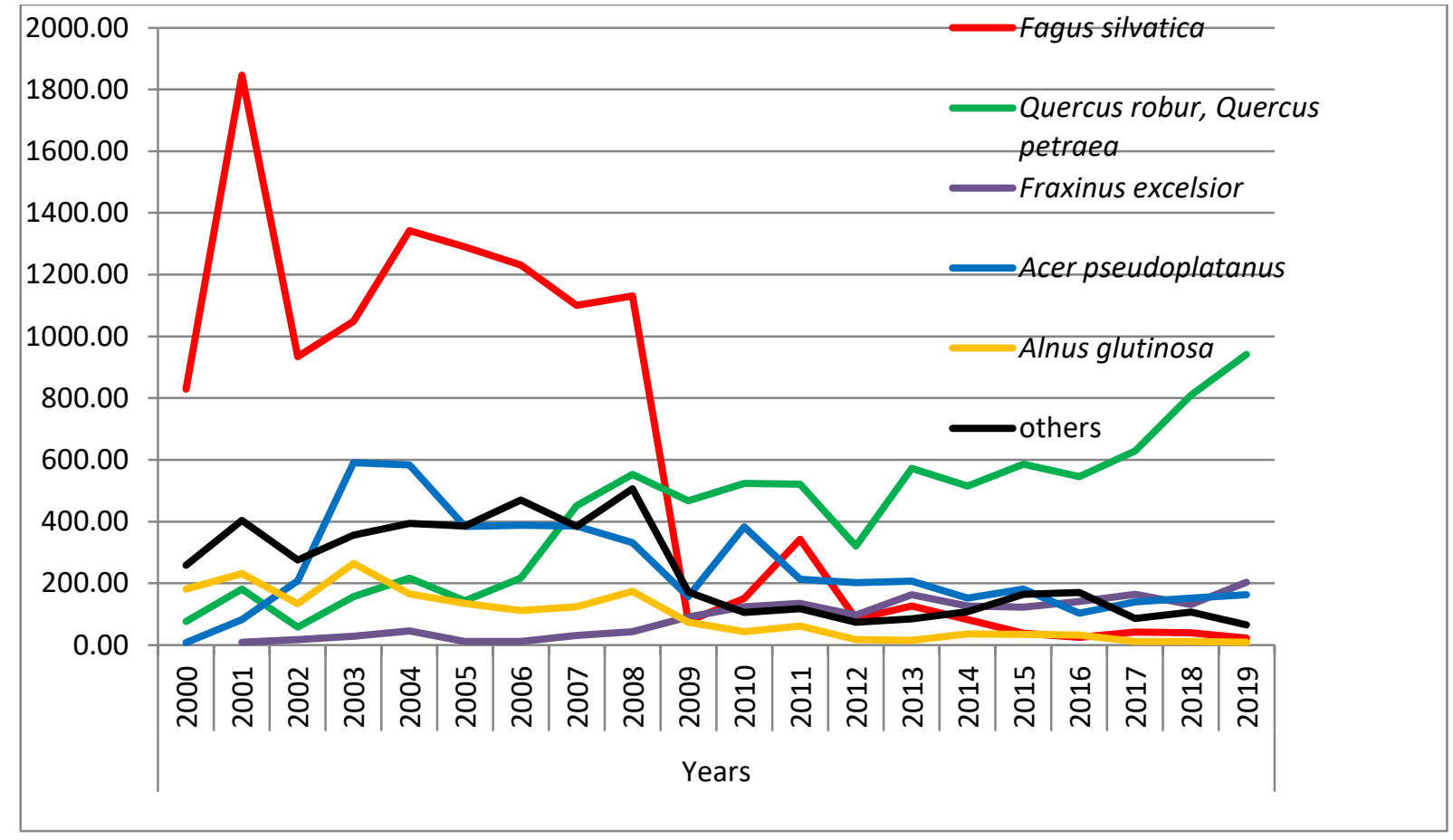

Fig. 2 Annually changes of amount of offered wood by species in $\mathrm{m}^{3}$.

After analyzing the results on prices obtained from the sale of wood on the valuable wood submission in 2000-2019, it was found that for species such as beech, birch, sycamore and black alder the lowest prices were recorded in 2006 and they ranged from PLN $109 / \mathrm{m}^{3}$ (28 \$) for sycamore to $166 \mathrm{PLN} / \mathrm{m}^{3}$ (42 \$) for black alder. On the other hand, the lowest prices for oak and ash wood were 
obtained in 2010 and they amounted to 251 and 321 PLN / m3 (63 \$ and 81 \$). Minimum prices throughout the analyzed period do not remain at a similar level but fluctuate.

The lowest average price of beech wood (the most common in the precious wood submission) was found in 2014 and it amounted to PLN $532 / \mathrm{m}^{3}$ (135 \$). In the case of sycamore wood, the lowest average price, amounting to PLN $948 / \mathrm{m}^{3}$ (240 \$), was achieved in 2000. In 2001, the lowest average price was obtained for oak wood, amounting to PLN $948 / \mathrm{m}^{3}(240 \$)$. The lowest average price for ash, PLN $494 / \mathrm{m}^{3}$ (125 \$), was obtained in 2003, and for black alder in 2015, PLN $606 / \mathrm{m}^{3}$ (153 \$).

In the analyzed period, the maximum price for ash and beech was obtained in 2003 and it was, respectively, PLN 4,719 and PLN 6,138 / $\mathrm{m}^{3}$ (1195 and 1554 \$). In 2004, the highest price in the history of the precious wood submission was achieved by black alder wood, for which PLN 2,976 / $\mathrm{m}^{3}(753$ \$) was paid, respectively. In 2006 the highest prices for sycamore were obtained, amounting to PLN $27,072 / \mathrm{m}^{3}(6854 \$)$. The highest price was paid for oak wood in 2019 , which amounted to PLN 4,585 $/ \mathrm{m}^{3}(1161 \$)$.

Wood raw material prices in Poland are close to the average prices in Europe. Every year, 30-39 companies from the wood industry, mainly from Poland, Austria and Germany, participate in the submissions, and the prices per $\mathrm{m}^{3}$ of wood achieved in the submissions are average two to three times higher than the prices achieved in ordinary forms of sale.

The obtained maximum prices of wood of individual species are not comparable with the minimum and average prices. The unit price obtained on the submissions may be due to the better quality of the displayed raw material and the greater interest of buyers in a given product in a given year [4]. Additional factors influencing the obtained unit price are: fashion in the furniture industry, trends in the wood market, demand for a given species, demand for wood and demand for specific wood raw materials in other countries, and the zloty exchange rate. All these factors make it difficult to determine the amount of wood that should be prepared each year for a precious wood submission, so that after deducting the costs incurred for its organization the economic results obtained were satisfactory.

The organization of the precious wood submission is a well-thought-out activity of the forest administration resulting from the increase in demand for wood of a certain quality, as individual veneering companies operating in the Krosno RDSF were purchasing only small amounts of the best quality raw material. In fact, there was much more of such wood, and the lack of competition had a direct impact on the sales volume and the level of prices achieved. However, the most important advantage of submissive sales is the ability to independently select the wood by the customer who, after examining the raw material, determines its suitability for production and makes a valuation. A very important effect of the organized precious wood submissions is the attraction of large and wellknown European veneer companies to the regional market in Poland. It would not be possible if this wood was sold in an amount from several to several dozen $\mathrm{m} 3$ directly by forest districts, because a small amount of wood purchased due to transport distances would not be an attraction for Austrian or German contractors. Selling timber on the sub-mission also allows you to gather enough timber for cost-effective transportation of dispersed species such as linden, elm or walnut which, due to local occurrence, have not been offered to buyers.

Thanks to the annual submissions of precious wood, it was possible to promote the local wood material from Podkarpacie not only in Europe, but also in the world through identification.

\section{Conclusions}

1. During the precious wood submissions organized by the Krosno RDSF in 2000-2019, a total of $30,994.52 \mathrm{~m}^{3}$ of wood was sold, with beech wood the most sold. Oak and sycamore wood was very popular among buyers.

2. The prices obtained during the precious wood submissions organized by the Krosno RDSF are constantly changing for individual species. The largest difference in the price of wood was found in 2006 for sycamore, where the minimum price per $1 \mathrm{~m}^{3}$ was PLN 109 (28 \$) and the maximum price was PLN 27,072 (6942\$). The average price for wood sold in the precious wood submission in the Krosno RDSF was PLN 1,270.74 / $\mathrm{m}^{3}$ (325 \$). 
3. Unit prices obtained for wood raw material depend on the demand for particular species, fashions in the furniture industry and trends in the wood market. On the other hand, the submission of valuable wood brings many regional and national benefits for the economy of the State Forests. Wood raw material prepared for the submission of valuable wood is of an increasingly better quality, new customers were also acquired and valuable wood was promoted on the European and global market.

4. The expectations of potential buyers as to the quality and dimensions of wood are getting higher and more difficult to meet by the State Forests. The organized submission of valuable wood enables the collection of wood that meets the requirements of the recipients. The supply of the highest quality wood fluctuates from year to year, while its average price increases.

\section{References}

1. Ustawa o lasach z dnia 28 września 1991 r. The Act on forests of September 28, 1991 1991. Dz. U. Nr 101, poz. 44.

2. Paschalis-Jakubowicz P., Kulik P., Lachowicz H. 2015. Kształtowanie cen oraz metody sprzedaży surowca cennego w Polsce. Prices and sales methods of the valuable timber in Poland. Sylwan, 159 (4): 267-277. DOI:10.26202/sylwan.2014116

3. Paschalis-Jakubowicz P., Kulik P., Lachowicz H. 2015. Obrót surowcem drzewnym najwyższych klas jakości w Polsce. Sales of the timber in the highest quality class in Poland. Sylwan, 159 (2): 91-102. DOI:10.26202/sylwan.2014112

4. Paschalis-Jakubowicz P., Kulik P., Lachowicz H. 2015. Potencjalna ilość surowca drzewnego najwyższych klas jakości w Polsce. Potential volume of the highest quality timber in Poland. Sylwan, 159 (3): 188-200. DOI:10.26202/sylwan.2014113

5. Zastocki D., Moskalik T., Sadowski J., 2015. Ocena submisji jako formy sprzedaży drewna najwyższej jakości. Assessment of submissions as a form of sale of the highest quality wood. Sylwan 159 (9): 707-713. DOI:10.26202/Sylwan.2015012

6. Zastocki D., Dobosz L., Moskalik T., Sadowski J. 2012. Submisja jako forma sprzedaży cennego surowca drzewnego. Submission as a form of sale of valuable timber. Sylwan 156 (4): 305-314. DOI:10.26202/Sylwan.2011069

7. Zastocki D., Dobosz L., Moskalik T., Sadowski J. 2012. Wyniki submisji drewna cennego na przykładzie RDLP Krosno. Valuable wood submissions on the example of Krosno RDSF. Sylwan 156 (7): 483-493. DOI:10.26202/Sylwan.2011111

Publisher's Note: MDPI stays neutral with regard to jurisdictional claims in published maps and institutional affiliations.

(C) 2020 by the authors; licensee MDPI, Basel, Switzerland. This article is an open access article distributed under the terms and conditions of the Creative Commons Attribution (CC-BY) license (http://creativecommons.org/licenses/by/4.0/). 